NEUROSCIENCE FOR NEUROLOGISTS

\title{
Molecular and cellular pathways of neurodegeneration in motor neurone disease
}

P J Shaw

J Neurol Neurosurg Psychiatry 2005;76:1046-1057. doi: 10.1136/jnnp.2004.048652

The process of neuronal degeneration in motor neurone disease is complex. Several genetic alterations may be involved in motor neurone injury in familial amyotrophic lateral sclerosis, less is known about the genetic and environmental factors involved in the commoner sporadic form of the disease. Most is known about the mechanisms of motor neurone degeneration in the subtype of disease caused by SOD1 mutations, but even here there appears to be a complex interplay between multiple pathogenic processes including oxidative stress, protein aggregation, mitochondrial dysfunction excitotoxicity, and impaired axonal transport. There is new evidence that non-neuronal cells in the vicinity of motor neurones may contribute to neuronal injury. The final demise of motor neurones is likely to involve a programmed cell death pathway resembling apoptosis.

Correspondence to: Professor Pamela J Shaw, Academic Neurology Unit, E Floor, School of Medicine and Biomedical Sciences, Beech Hill Road, Sheffield S10 2RX; Pamela.Shaw@sheffield. ac.uk

Received

30 November 2004

In revised form

21 January 2005

Accepted 21 January 2005
M otor neurone disease (MND), known in many countries as amyotrophic lateral sclerosis (ALS), is the commonest adult onset disorder of motor neurones, and among the most common of adult onset neurodegenerative diseases. The incidence of the disease is the world, with the exception of several high incidence foci, for example on the island of Guam in the Western Pacific and on the Kii peninsula of Japan. The lifetime risk of developing ALS/MND is approximately 1 in 2000. At any one time there are approximately 5000 individuals suffering from MND in the United Kingdom. Some epidemiological studies indicate that the incidence of MND may be increasing, though the contribution to this of population aging and better developed neurological diagnostic services is currently unknown. ${ }^{1}$ The disease is predominantly a condition of middle age and elderly life, with an average age of onset between 50 and 60 years, though rare juvenile onset forms of the condition also exist. For reasons that are not currently understood, MND affects men more commonly than women, with a male to female ratio of approximately $1.6 / 1 .^{2}$

The pathology accompanying the clinical phenotype was first described by Jean-Martin Charcot in 1869. ${ }^{3}$ The salient pathological feature is progressive injury and cell death of lower motor neurone groups in the spinal cord and brain stem and of upper motor neurones in the motor cortex. Characteristic cytopathological features in motor neurones not yet eliminated 1-2 per 100000 and is fairly uniform throughout during the disease process are the presence of ubiquinitated proteinaceous inclusions within motor neurone cell bodies, and neurofilament accumulations within motor neurone axons. ${ }^{4}$

The person afflicted by MND typically develops a combination of upper and lower motor neurone signs, with progressive muscle weakness and wasting, usually accompanied by pathologically brisk reflexes, eventually involving the limb and bulbar muscles. Clinical variants of the disease may initially affect only the spinal lower motor neurones (progressive muscular atrophy variant); only the upper motor neurones (primary lateral sclerosis variant); or only the bulbar musculature (progressive bulbar palsy variant). With disease progression, the majority of patients will develop features of ALS. Certain motor neurone groups are less vulnerable to the pathological process, including those in upper brain stem nuclei controlling eye movements, and those in Onuf's nucleus within the sacral spinal cord controlling the pelvic floor musculature. ${ }^{5}$ The rate of disease progression varies between individuals, but the average survival is only of the order of three years from symptom onset. ${ }^{6}$ However, approximately $10 \%$ of patients will have a slower disease course with survival beyond 10 years. ${ }^{7}$ Death in most patients results from neuromuscular respiratory failure. The World Federation of Neurology diagnostic criteria for ALS/MND require the presence of signs of upper and lower motor neurone degeneration, with evidence of progression, in the absence of evidence of other disease processes. ${ }^{8}$

The selectivity of the pathological process for the motor system is now recognised to be relative rather than absolute. Detailed investigation has revealed involvement of extramotor parts of the CNS, including changes in other long tract systems-for example, sensory and spinocerebellar pathways - and cellular injury of neuronal groups including the substantia nigra neurones and dentate granule cells within the hippocampus. ${ }^{9}$ Overt dementia is found in approximately $2-3 \%$ of MND patients, ${ }^{10}$ and detailed neuropsychological testing shows more subtle neurophysiological changes, particularly affecting frontal function, in approximately $30 \%$ of patients. ${ }^{11}$ Thus MND is now regarded as a multisystem disease in which motor neurones tend to be affected earliest and most prominently. ${ }^{4}$

Abbreviations: ALS, amyotrophic lateral sclerosis; CNTF, ciliary neurotrophic factor; GEF, guanine nucleotide exchange factor; HRE, hypoxia response element; MND, motor neurone disease; VAPB, vesicle associated membrane protein/synaptobrevin associated membrane protein; VEGF, vascular endothelial growth factor 


\section{WHAT DO WE KNOW ABOUT THE CAUSES OF MOTOR NEURONE DEGENERATION?}

The primary pathogenic processes underlying MND are likely to be multifactorial, and the precise mechanisms underlying selective cell death in the disease are at present unknown. Current understanding of the neurodegenerative process in MND suggests that there may be a complex interplay between multiple mechanisms including genetic factors, oxidative stress, excitotoxicity, protein aggregation, and damage to critical cellular processes, including axonal transport and organelles such as mitochondria (table 1). Recently there has been growing interest in the role played by non-neuronal neighbourhood cells in the pathogenesis of motor neurone injury and in dysfunction of particular molecular signalling pathways (fig 1). The relative importance of these different pathways may well vary in different subgroups of patients, and a very important task for clinicians and scientists in the future is to further delineate the subcategories of MND. Evidence has also accumulated that the final process of motor neurone death is likely to occur through a caspase dependent programmed cell death pathway resembling apoptosis.

\section{GENETICS OF ALS/MND}

MND is sporadic in $90-95 \%$ of cases and familial in approximately $5-10 \%$. Inheritance in familial MND is usually autosomal dominant, though autosomal recessive and $X$ linked inheritance may be seen in some pedigrees. It is apparent that multiple abnormal gene products can set the scene for motor neurone degeneration. There are at least six dominantly inherited adult onset ALS genes (table 2), of which only three have so far been identified.

\section{Copper-zinc superoxide dismutase (SOD 1)}

A major research breakthrough 11 years ago came from the finding that $20 \%$ of families with autosomal dominant MND showed mutations in the gene on chromosome 21q22.1 which encodes the free radical scavenging enzyme superoxide dismutase 1 (SOD1). ${ }^{12}$ More than 100 different mutations have been identified throughout the SODl gene. ${ }^{13}{ }^{14}$ The majority of mutations in SODl are missense mutations, with a small number of deletion and insertion mutations resulting in truncated SOD1 polypeptides. SOD1 is a metalloenzyme of 153 amino acids which functions as a homodimer whose major function is to convert intracellular superoxide free radicals - a toxic waste product of mitochondrial oxidative phosphorylation-to hydrogen peroxide which is in turn removed by the action of other free radical scavenging enzymes. The SODl enzyme contains an essential copper atom at the active site which is alternately reduced and oxidised by superoxide. The presence of zinc is thought to stabilise the protein structure. SODl is an abundant protein in the CNS, accounting for about $1 \%$ of brain protein,

Table 1 Pathogenic mechanisms which may contribute to motor neurone injury and cell death in motor neurone disease

Genetic factors

- Oxidative stress

- Protein aggregation

- Glutamatergic toxicity

- Mitochondrial dysfunction

- Impairment of axonal transport

- Inflammatory cascades/contribution of non-neuronal cells

- Dysfunctional signalling pathways, eg through VEGF, Nrf2

The above factors alone or in combination may lead to a programmed cell death mechanism similar to apoptosis but it is also ubiquitously expressed in all other tissues. SOD 1 was initially thought to be confined to the cytosolic compartment of cells but it is now recognised that a small proportion of the protein is located in the intermembrane space of the mitochondria. ${ }^{15}$ The reasons why motor neurones are especially vulnerable to injury in the presence of SODl mutations are not yet clear.

Despite 11 years of intensive research effort, the pathways leading to the cell death of motor neurones in the presence of SODl mutations have not yet been fully identified, though there is a convincing body of evidence that the mutant SODl protein exerts its detrimental effects through a toxic gain of function rather than a loss of function. Most of our current level of understanding of disease mechanisms in ALS/MND has come from the study of the effects of SODl mutations, but even in this defined genetic subgroup of disease the pathways to neurodegeneration appear to be complex and multifactorial. ${ }^{16}$

There is considerable variation in disease phenotype in terms of age of onset and rate of disease progression in human SODI related MND. It is apparent that the clinical phenotype must be modified by other genetic or environmental factors, or both. There has been much interest in the D90A SODl mutation, which has a dominant inheritance in some genetic backgrounds but is recessively inherited, with two mutated copies of the gene required to cause disease, in Scandinavian populations, implying a co-inherited protective factor. ${ }^{17}$ Some intensively studied SODl mutations such as the A4V mutation do not show $100 \%$ penetrance $^{18}$ and the disease phenotype in mice can vary significantly according to the background strain of mouse employed. ${ }^{19}$

Mutant SODI transgenic mice that develop a disease which clinically and pathologically resembles human MND have been developed. The most extensively studied are SODI G93A, SODl G37R, and SODl G85R.20-22 Transgenic rats, carrying G93A or H46R SODl, also develop an MND phenotype. $^{23}{ }^{24}$ In addition, cellular models of SODl related MND have been generated which have helped to elucidate cellular mechanisms of disease..$^{25-27}$

The toxic gain of function of mutant SOD1 has not yet been fully defined, but several pathophysiological processes may be involved, including oxidative stress, mitochondrial dysfunction, excitotoxicity, protein aggregation, and inflammation. These mechanisms are not mutually exclusive and it is possible that all of them play a role in the development of motor neurone injury. These potential mechanisms will be discussed in subsequent sections.

The genetic alterations underlying the remaining $80 \%$ of cases of autosomal dominant MND at present remain unknown. However, three other genes have recently been identified as causative in rare cases of familial MND.

\section{ALS 2: alsin}

In 2001, two groups identified alsin as the causative gene for an autosomal recessive form of juvenile ALS linked to chromosome $2 \mathrm{q} 33 .^{28}{ }^{29}$ Mutations in alsin can also cause a motor neurone degenerative disorder with a predominant upper motor neurone phenotype, infantile onset ascending hereditary spastic paralysis, ${ }^{30}{ }^{31}$ and one family has been described with autosomal recessive complicated hereditary spastic paraplegia. ${ }^{32}$ Thus, ALS2 mutations account for several juvenile onset autosomal recessive neurodegenerative disorders of motor neurones.

ALS2 encodes a $184 \mathrm{kDa}$ protein which contains three putative guanine nucleotide exchange factor (GEF) domains. GEFs are known to activate small GTPase proteins by stimulating the release of guanosine diphosphate (GDP) in exchange for guanosine triphosphate (GTP). ${ }^{33}$ Given the conserved GEF domains of ALS2, it is predicted to function as 


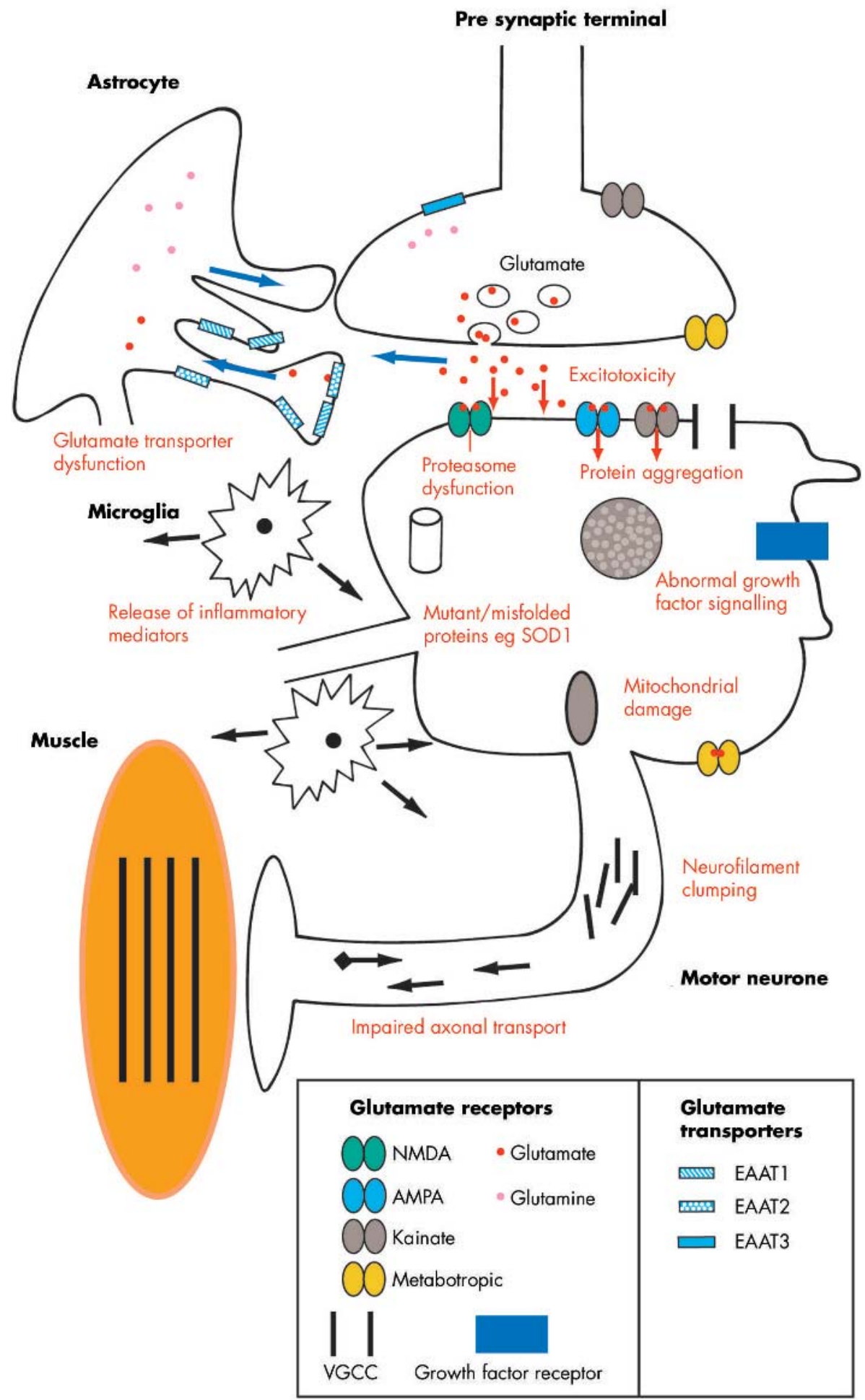

Figure 1 Molecular mechanisms that may contribute to motor neurone injury in motor neurone disease.

an activator of particular small GTPases. The small GTPases control a range of important cellular processes including nuclear transport, cytoskeletal reorganisation, transcription, cell migration, and membrane trafficking. They function as binary switches-alternating between inactive GDP bound and active GTP bound states. The alsin protein is widely expressed, but enriched within the CNS, where it is localised to the cytoplasmic face of endosomal membranes. ${ }^{34}$ The functions of alsin are still being worked out, but to date it has been shown to bind specifically to the small GTPase, Rab5, and to function as a guanine nucleotide exchange factor or activator of Rab5. ${ }^{35}{ }^{36}$ This implies that alsin is important in endosomal dynamics, and the working hypothesis is that it normally regulates trafficking of signalling molecules 
Table 2 Genetic subtypes of ALS/MND

\begin{tabular}{lll}
\hline Subtype of ALS/MND & Gene & Inheritance, chromosome \\
\hline ALS1 & SOD1 & Dominant-adult onset, 21q22.1 \\
ALS2 & ALSIN & Recessive-juvenile onset, 2q33 \\
ALS3 & - & Dominant-adult onset, 18q21 \\
ALS4 & Senataxin (SETX) & Dominant-juvenile onset, 9q34 \\
ALS5 & - & Recessive-iuvenile onset, 15q15.1-q21.1 \\
ALS6 & - & Dominant-adult onset, 16q12 \\
ALS7 & - & Dominant-adult onset, 20ptel-p13 \\
ALS8 & Vesicle associated membrane protein & Dominant-adult onset, 20q13.33 \\
ALS-FTD & (VAPB) & Dominant-adult onset, 9q21-22 \\
ALS-X & - & Dominant-adult onset, Xp11-q12 \\
ALS with parkinsonism and & - Microtubule associated protein tau & Dominant-adult onset, 17q21 \\
dementia & (MAPT) & \\
Progressive LMN disease & Dynactin p150 subunit (DCTN1) & Dominant-adult onset, 2p13 \\
\hline \multirow{2}{*}{ ALS, amyotrophic lateral sclerosis; LMN, lower motor neurone; MND, motor neurone disease. }
\end{tabular}

important for proper development or maintenance of the health of motor neurones. ALS2 knockout mice have been generated but no major motor system disease phenotype has yet been reported. ${ }^{3738}$

Alsin/ALS2 is alternatively spliced to generate a short and a long transcript. It has recently been reported that the long isoform of alsin specifically binds, through its RhoGEF domain, to mutant SODl and protects cultured motor neurones from mutant SODl mediated toxicity. ${ }^{39}$ Further examination of this interaction may help elucidate motor neurone specific pathways of neurodegeneration.

\section{ALS4: senataxin}

The ALS4 locus linked to chromosome 9q34 was originally identified in a single large pedigree with juvenile onset, autosomal dominant ALS/MND. The disease course in this family was indolent and did not reduce life expectancy. Chen and colleagues identified three different missense mutations (L3095, R2136H, and T3I) in three families with this subtype of ALS/MND. ${ }^{40}$ The SETX gene encodes senataxin, a large $302.8 \mathrm{kDa}$ protein of unknown function. Much of the protein has no homology with other known proteins, but there is one DNA/RNA helicase domain. DNA/RNA helicase proteins are known to have roles in processes such as repair, replication, recombination or transcription of DNA and RNA processing, RNA transcript stability, and the initiation of translation. Recessive loss of function mutations in SETX are associated with ataxia-oculomotor apraxia type $2 .{ }^{41}$ It is predicted that the different phenotype of dominantly inherited ALS4 is likely to be caused by a toxic gain of function of the mutated senataxin protein.

\section{ALS8: VAPB (vesicle associated membrane protein/ synaptobrevin associated membrane protein)}

Very recently Nishimura and coworkers described a novel missense mutation (P565) in the VAPB gene at chromosome 20q 13.3 in a Brazilian family with ALS8, an autosomal dominant slowly progressive disorder characterised by fasciculation, cramps, and postural tremor. ${ }^{42}$ They subsequently found the same mutation in six further families with different clinical phenotypes, including late onset spinal muscular atrophy and classical rapidly progressive ALS/MND. Thus, modifier genes or environmental factors are likely to play an important role in modulating the clinical course of disease in individuals carrying the same mutation. Vesicle associated proteins are intracellular membrane proteins that can associate with microtubules and have been shown to function in membrane transport. The VAPB protein has three identifiable structural domains. The first 150 residues form an MSP domain conserved between all members of this protein family; the central region contains an amphipathic helical structure predicted to form a coiled/coil proteinprotein interaction motif and at the carboxy terminus is a hydrophobic region that acts as a membrane anchor. Preliminary cell biological studies have indicated that the wild-type VAPB protein localises predominantly to the endoplasmic reticulum. The P56S mutation dramatically disrupts the subcellular distribution and induces the formation of intracellular protein aggregates. ${ }^{42}$

\section{Dynactin mutation}

Puls and colleagues identified a mutation (G595) substitution in the gene encoding the P150 subunit of dynactin (DCTN1) in a single family with a slowly progressive lower motor neurone degenerative disorder. ${ }^{43}$ The described family had a highly unusual and characteristic phenotype, presenting in early adulthood with respiratory difficulties from vocal cord paralysis, progressive facial weakness, weakness and atrophy of the hands, and the later development of lower motor neurone signs distally in the lower limbs. The amino acid change caused by the mutation would be predicted to distort the folding of the microtubule binding domain of dynactin.

The dynactin-protein complex is required for dynein mediated retrograde axonal transport of vesicles and organelles along the microtubule system. It provides the link between the specific cargo, the microtubule, and cytoplasmic dynein during vesicle transport. Interestingly, it has also been shown that overexpression of the P50 subunit of dynactin also disrupts the function of this protein complex and causes late onset progressive motor neurone degeneration in genetically engineered mice. ${ }^{44}$

\section{Other ALS/MND loci}

The genes for several other subtypes of ALS remain to be identified, as indicated in table 2. Three separate families have shown linkage to chromosome 16, allowing significant refinement of the region of interest. ALS/MND with frontotemporal dementia has been mapped to a 17-cM interval chromosome $9 \mathrm{q} 21,{ }^{45}$ and one Swedish family with a similar phenotype without linkage to the chromosome 9 locus has recently been identified, suggesting genetic heterogeneity for this subtype of disease. ${ }^{46}$ Motor neurone degeneration may sometimes occur in patients with fronto-temporal dementia and Parkinson's disease, associated with mutations in the microtubule associated protein tau. ${ }^{47} 48$ The mutant tau protein forms filamentous inclusions and insoluble aggregates that are associated with neurodegeneration. Some patients with familial fronto-temporal dementia, parkinsonism, and ALS/MND do not have identified mutations in tau, ${ }^{49}{ }^{50}$ suggesting that further genes causing this triad of features remain to be identified. 
Possible genetic risk factors in sporadic ALS/MND There have been reports of genetic variants found in individuals with apparently sporadic MND (table 3). Deletions or insertions have been described in the KSP repeat region of the gene encoding the neurofilament heavy protein, which is a major component of the neuronal cytoskeleton..$^{51}{ }^{52}$ The apolipoprotein E $\Sigma 4$ genotype, which correlates with an earlier age of onset in Alzheimer's disease, has been examined in ALS/MND and the results obtained are not clear. Some studies have indicated that the apolipoprotein $\Sigma 4$ genotype may be a risk factor for the development of bulbar onset ALS. ${ }^{53}$ Another study provided evidence that this genotype correlates with a shortened survival in patients with ALS, though it did not obviously influence age of onset. ${ }^{54}$ However, several other groups have been unable to confirm these findings. A single patient with an ALS/MND phenotype has been described with a mutation in the mitochondrially encoded subunit $\mathrm{l}$ of cytochrome $\mathrm{C}$ oxidase, which is an important component of the mitochondrial respiratory chain..$^{55}$ Decreased expression of the glial glutamate transporter $\mathrm{EAAT}_{2}$ is observed in the spinal cord of human ALS/ MND patients and in mouse and rat SODl transgenic murine models. ${ }^{24}$ 56-58 Initially it was suggested that aberrant splicing of $\mathrm{EAAT}_{2} \mathrm{RNA}$ might underlie this alteration in transporter expression, ${ }^{59}$ but subsequent studies have indicated that $\mathrm{EAAT}_{2}$ splice variants are observed as frequently in the CNS of controls as in patients with ALS/MND. ${ }^{60}{ }^{61}$ A single individual with sporadic ALS/MND has been found to have a mutation (N2065) within a putative glycosylation site of EAAT2, which appeared functionally significant in causing aberrant targeting to the cell membrane and reduced glutamate transport. ${ }^{62} \mathrm{~A}$ further component of the glutamate neurotransmitter system has been found to be altered in ALS/ MND. Kawahara and colleagues reported that the editing of the GluR2 AMPA receptor subunit appeared defective in motor neurones isolated from ALS spinal cord.$^{63}$ The normal RNA editing process of this receptor subunit changes a glutamine to an arginine residue in almost $100 \%$ of transcripts, with the important functional consequence that the encoded AMPA receptor channel is impermeable to calcium.

Homozygous deletions of the survival motor neurone gene (SMN1) located on chromosome 5 cause autosomal recessive proximal spinal muscular atrophy, usually of childhood onset. A second adjacent gene, SMN2, has five nucleotide differences between intron 6 and exon 8 which distinguish it from SMN1. One of these polymorphic variants causes frequent skipping of exon 7 , which in turn results in low expression of full length SMN2 protein. Two early studies failed to provide evidence for homozygous deletion of SMNI in sporadic ALS. ${ }^{64}{ }^{65}$ Several studies have been conducted to determine whether alterations of SMN1 or SMN2 are associated as genetic risk factors for ALS. The results are conflicting. Veldink and coworkers found that SMN2 gene deletions were overrepresented in patients with sporadic ALS
( $16 \%$ ALS patients $v 4 \%$ of controls). ${ }^{66}$ Corcia et al reported no difference in SMN2 copy number, but that patients with ALS were significantly more likely to have an abnormal copy number of SMN1 (one or three copies). ${ }^{67}$ Further work is necessary to determine whether alterations in SMN copy number are true risk factors for the development of ALS.

Ciliary neurotrophic factor (CNTF) is a potent survival factor for motor neurones. Inactivation of the CNTF gene causes mild progressive motor neurone loss in adult mice but does not result in an ALS/MND phenotype. A splice site acceptor mutation in the CNTF gene causes a null mutant allele lacking biological activity, and $1-2 \%$ of the normal human population are homozygous for this null allele. A study of SODl related familial ALS/MND with a V148G mutation and marked intrafamilial variation in the clinical phenotype indicated that a homozygous null mutation in CNTF might correlate with early onset and rapid disease progression. ${ }^{68}$ In addition, G93A SODl mice crossed with CNTF knockout mice developed disease at a significantly earlier age.

Vascular endothelial growth factor (VEGF) is an angiogenic factor essential for the formation of new blood vessels during embryogenesis and in many pathological conditions, and has also recently been found to have a significant role as a neurotrophic factor. ${ }^{69}$ The expression of VEGF is normally upregulated as a response to tissue hypoxia. Lambrechts et al have recently shown that VEGF is a modifier of ALS/MND in both humans and mice. ${ }^{70}$ Deletion of the hypoxia response element (HRE) from the VEGF promoter in mice unexpectedly caused a late onset motor neurone disease which resembled ALS. ${ }^{71}$ Cross breeding of these VEGF mice with G93A SODl transgenic mice resulted in a worsening of the phenotype with earlier onset of disease. No mutations of the HRE of VEGF have been identified in human ALS/MND. ${ }^{70}$ In a meta-analysis of a pooled population of 1900 individuals from four different European populations, two "at risk" haplotypes of promoter $\left(5^{\prime}\right)$ polymorphisms were identified which conferred an overall 1.8-fold increased risk of ALS/ MND. These haplotypes were associated with lower serum VEGF levels in both control and ALS/MND populations and with reduced in vitro transcription of a luciferase reporter gene. ${ }^{68}$ There was substantial heterogeneity in terms of the risk of ALS/MND associated with VEGF promoter polymorphisms between the different geographical groups of patients included in this study, and some studies with smaller numbers of patients and controls have shown that these polymorphisms do not confer an increased risk of ALS/ MND. ${ }^{72}{ }^{73}$ Thus further exploration of the role of VEGF in the pathogenesis of human ALS/MND is required.

\section{OXIDATIVE STRESS}

The effects of oxidative stress within non-dividing cells such as neurones may be cumulative, and cellular injury by free radical species is a major potential cause of the age related deterioration in neuronal function that occurs in

Table 3 Potential genetic risk factors in sporadic ALS/MND and genetic modifiers in familial ALS/MND

\begin{tabular}{llll}
\hline Gene & Chromosome & Genetic variant & ALS association \\
\hline Neurofilament heavy (NEFH) & $22 q 12.1-q 13.1$ & KSP deletion/insertion & Sporadic \\
Apolipoprotein E (Apo E $\Sigma 4$ ) & $19 q 13.2$ & S4 genotype & Sporadic \\
Cytochrome c oxidase subunit 1 & Mt & Microdeletion & Sporadic \\
Excitatory amino acid transporter 2 (EAAT 2$)$ & $11 p 13-p 12$ & Decreased expression & Familial/sporadic \\
AMPA receptor subunit (GluR2) & $4 q 32-q 33$ & Altered RNA editing & Sporadic \\
? Survival motor neurone 1 (SMN1) & $5 q 12.2-q 13.3$ & Copy number & Sporadic \\
? Survival motor neurone 2 (SMN2) & $5 q 12.2-q 13.3$ & Copy number & Sporadic \\
Ciliary neurotrophic factor (CNTF) & $11 q 12.2$ & Null allele & Familial \\
Vascular endothelial growth factor (VEGF) & $6 p 12$ & Promotor polymorphisms & Sporadic \\
\hline ALS, amyotrophic lateral sclerosis; MND, motor neurone disease. & & \\
\end{tabular}


neurodegenerative diseases. There has been particular interest in the role of oxidative stress in ALS/MND, given that mutations in SODl-which encodes a key cellular antioxidant defence protein-underlie around $20 \%$ of familial ALS/ MND cases. The close clinical and pathological similarity between sporadic and SODl related familial subtypes of MND suggest that common pathophysiological mechanisms may be operating. Studies of CSF and human postmortem CNS tissue have shown the presence of biochemical changes which represent the effects of free radical damage or abnormal free radical metabolism, and these changes are more pronounced in ALS/MND cases than in controls. ${ }^{74-77}$ Fibroblasts cultured from the skin of patients with both familial and sporadic MND show increased sensitivity to oxidative insults compared with those from control cases. ${ }^{78}$

In relation to the toxic gain of function of the mutant SODl protein, oxidative damage or metal mishandling, or both, have been strongly implicated. The main hypotheses have been that mutations alter the structure of the SODl protein, allowing greater access of abnormal substrates to the active copper site of the dimeric enzyme, resulting in the production of damaging free radical species including peroxynitrite and hydroxyl radicals. Nitration of tyrosine residues on cellular proteins by peroxynitrite can have damaging consequences. ${ }^{79}$ Some mutations in SODl render the protein more likely to form a zinc deficient variant, ${ }^{80} 81$ which in turn makes the copper site more accessible to abnormal substrates. In vitro studies have shown that zinc deficient SODl causes peroxynitrite dependent cell death. ${ }^{81}$ However, several experiments have raised questions as to whether the toxicity of mutant SODl can be explained by copper dependent oxidative mechanisms. Thus SODl that has been engineered not to bind copper by mutating the four histidine residues for copper binding still causes ALS/MND in transgenic mice. ${ }^{82}$ Also, knock out of the gene encoding the copper chaperone protein normally required for insertion of copper into SODl has no effect on the disease phenotype in SODl transgenic mice. ${ }^{83}$ Finally, reduction in nitric oxide (NO) synthesis by pharmacological inhibition of neuronal nitric oxide synthase (nNOS) or genetic manipulation of nNOS would be expected to ameliorate the disease phenotype in mutant SODl transgenic mice if peroxynitrite is indeed a key contributor to motor neurone injury. However, these interventions have not been shown to have a significant effect on the murine disease, ${ }^{84}{ }^{85}$ nor did deletion of inducible NOS, which is normally expressed within astrocytes and microglia. ${ }^{86}$

\section{EXCITOTOXICITY}

Glutamate is the major excitatory transmitter in the human CNS, and tremendous complexity has been uncovered in the molecular structure of the repertoire of receptors for this neurotransmitter system. Excitotoxicity is the term coined for neuronal injury induced by excessive stimulation of glutamate receptors, by mechanisms which include derangement of intracellular calcium homeostasis and excessive free radical production. Motor neurones are particularly susceptible to toxicity through activation of cell surface AMPA receptors. ${ }^{87}$ A body of evidence, which is still circumstantial, has implicated glutamatergic toxicity as a contributory factor to motor neurone injury (reviewed by Heath and Shaw ${ }^{88}$ ). The key findings are that the expression and function of the major glial glutamate reuptake transporter protein $\mathrm{EAAT}_{2}$ may be impaired in the CNS of MND patients and that CSF (and therefore CNS extracellular fluid) levels of glutamate appear to be abnormally raised at least in a proportion of MND patients. ${ }^{5658990}$ The balance of evidence does not favour RNA mis-splicing as the cause of reduced $\mathrm{EAAT}_{2}$ expression as discussed above.
Excitotoxicity has provided one of the few examples of a mechanistic link between mutant SODl mediated MND and the sporadic form of the disease. The presence of mutant SODl increases the sensitivity of motor neurones to glutamate toxicity, ${ }^{27}{ }^{91}$ causes alteration in AMPA receptor subunit expression, ${ }^{92}$ and causes reduced expression of the major glutamate reuptake transporter $\mathrm{EAAT}_{2}{ }^{24}{ }^{93}$

Whether as a primary or a propagating process, it appears that glutamate toxicity plays a contributory role to the injury of motor neurones in ALS/MND. This is supported by the finding that anti-glutamate treatment with riluzole has some effect, albeit modest, in prolonging survival in human ALS patients and in mutant SODI mouse models. ${ }^{94} 95$

\section{MITOCHONDRIAL DYSFUNCTION}

Important properties of mitochondria include the generation of intracellular ATP, the buffering of intracellular calcium, the generation of intracellular free radicals, and involvement in the initiation of apoptotic cell death. Age related deterioration in mitochondrial function is considered a potentially important factor contributing to late onset neurodegenerative diseases.

There is a body of evidence emerging from investigation of human material and cellular and animal models indicating that mitochondrial dysfunction may contribute to motor neurone injury in ALS/MND, and this has been reviewed. ${ }^{96}{ }^{97}$ The key evidence for mitochondrial dysfunction in human ALS/MND includes the following:

- alteration in the morphology of mitochondria in hepatocytes, muscle, and motor neurones;

- increased mitochondrial volume and calcium levels within motor axon terminals in muscle biopsies from sporadic ALS/MND cases $^{98}$;

- reduced complex IV activity in spinal motor neurones in sporadic ALS ${ }^{99}$;

- high frequency of mitochondrial DNA mutations in motor cortex tissue in sporadic ALS ${ }^{100}$;

- multiple mutations and decreased mitochondrial DNA in muscle and spinal cord in sporadic ALS ${ }^{101}$;

- ALS-like phenotype in one patient with a deletion in the cytochrome oxidase c subunit/gene. ${ }^{55}$

Further evidence for the role of mitochondrial dysfunction as a contributory factor to motor neurone injury has come from the examination of cellular models of SODl related ALS/MND. Expression of mutant (G93A) SOD1 in the NSC34 motor neurone cell line results in the development of morphologically swollen mitochondria, impaired activity of complexes II and IV of the mitochondrial respiratory chain, impaired cellular bioenergetic status, and alteration in the mitochondrial proteome. ${ }^{102} 103$ Takeuchi and colleagues showed that molecular targeting of mutant SODl to the mitochondria but not to the nucleus or endoplasmic reticulum leads to activation of the apoptosis cascade and cell death. ${ }^{104}$

Mitochondrial dysfunction has also been studied in mutant SODl transgenic mice. At least in some strains (for example, G93A) mitochondrial vacuolation within motor neurones is an early feature of the pathology. ${ }^{20}$ Whereas SODl was previously considered to be an exclusively cytosolic protein, it is now recognised also to reside in the intermembrane space of mitochondria. ${ }^{105}$ SODI has been shown to accumulate in vacuolated mitochondria in mutant SODI mice. ${ }^{106}$ It has been shown that the activities of several complexes of the mitochondrial respiratory chain are reduced before disease onset and that these changes increase with age. ${ }^{107}$ Mattiazzi and colleagues reported the presence of oxidative damage to mitochondrial protein and lipids and decreased ATP synthesis 
at the onset of the murine disease. ${ }^{108}$ Several groups have shown translocation of cytochrome $\mathrm{C}$, an initiator of apoptosis, from the mitochondria to the cytosol during disease progression in the mouse. ${ }^{109} 110$ Partial deficiency of the mitochondrial form of SOD (MnSOD) exacerbates disease in transgenic SODl mice. ${ }^{111}$ Recently Lui et al reported that mutant SODI is selectively and aberrantly recruited to the cytoplasmic face of mitochondria in spinal cord tissue from mutant SODl transgenic mice. Covalently damaged adducts of mutant SOD accumulated on the cytoplasmic face of mitochondria in the spinal cord. ${ }^{112}$ This tissue specific recruitment raises the possibility that mitochondrial abnormalities may be involved in the initiation of motor neurone injury. Pasinelli et al also recently showed that the antiapoptotic protein $\mathrm{Bcl} 2$ may be entrapped within large protein aggregates of SOD1 in spinal cord tissue, which may result in reduction of the availability of this protein to regulate apoptosis. ${ }^{113}$

Therapeutic effects of compounds which modulate mitochondrial function have begun to be investigated in SODl transgenic mouse models. Creatine buffers energy levels within the cell, maintains ATP levels, and stabilises mitochondrial creatine kinase, which inhibits opening of the mitochondrial permeability transition pore. Administration of creatine to G93A transgenic mice improved motor function and extended survival in a dose dependent manner, as well as causing a reduction in biochemical indices of oxidative damage in the spinal cord. ${ }^{114}$ Minocycline, a tetracycline derivative which inhibits microglial activation and blocks release of cytochrome c from mitochondria, also slows disease in mutant SODl mice. ${ }^{10}$

\section{CYTOSKELETAL ELEMENTS AND AXONAL TRANSPORT}

Neurofilament proteins form a major component of the cytoskeleton of neurones, and important functions include maintenance of cell shape and axonal calibre, as well as axonal transport. Neurofilaments are the most abundant structural proteins in large cells with long axons such as motor neurones. Neurofilament subunits are assembled in the motor neurone cell body, and transported down the axon by slow axonal transport, with progressive phosphorylation during movement down the axon.

Neurofilament proteins are potential subcellular targets for injury in ALS/MND and other forms of motor neurone degeneration. Accumulation and abnormal assembly of neurofilaments are common pathological hallmarks of ALS/ MND. Ubiquitinated inclusions with compact or Lewy bodylike morphology within surviving motor neurones in ALS/ MND may show immunoreactivity for neurofilament epitopes. In some cases of SODl related ALS, large argryophilic hyaline conglomerate inclusions expressing both phosphorylated and non-phosphorylated neurofilament epitopes have been observed in the cell bodies and axons of motor neurones. ${ }^{4}$ The importance of neurofilaments in the normal functioning of motor neurones is demonstrated by the finding that approximately $1 \%$ of sporadic ALS/MND cases have deletions of insertions in the KSP repeat region of the neurofilament heavy (NFH) gene. ${ }^{51}{ }^{52}$ In addition, pathological changes within motor neurones develop in mice overexpressing NF-light or NF-heavy subunits, or in mice expressing mutations in the NF-light gene. ${ }^{115-117}$ Transgenic mice which carry mutations in SODl also show alterations in neurofilament organisation, with the development of neurofilament spheroids, as well as reduced neurofilament protein and decreased transport rate in the ventral root axons. ${ }^{118} 119$ Genetic manipulations to alter the expression of neurofilament proteins have been shown to alter the disease course in SODl transgenic mice. Increased expression of NF-heavy, which traps most neurofilaments within the cell body, robustly improves the disease course-by as much as six months in mutant SODl mice. ${ }^{120}$ The reasons for this somewhat counterintuitive effect are not understood, though it has been suggested that excess neurofilaments within the cell body may function as a buffer for some other deleterious process, for example offering phosphorylation sites for dysregulated intracellular kinases, or reducing the burden of axonal transport.

Another intermediate filament protein, peripherin, may play a role in motor neurone degeneration. Genetically engineered mice which overexpress the major peripherin isoform (peripherin 58) develop late onset motor neurone degeneration accompanied by disruption of neurofilament assembly. ${ }^{121}$ Another isoform, peripherin 61, is toxic when expressed in primary motor neurones and this toxic isoform is detectable in the spinal cord of sporadic ALS/MND cases. ${ }^{122}$ However, manipulating the level of expression of peripherin in SODl transgenic mice does not appear to have any effect on the disease phenotype. ${ }^{123}$

Motor neurones, which in the human nervous system may have axons up to one metre in length, are highly reliant on an efficient intracellular transport system with anterograde and retrograde components. It is interesting that in SODl mutant mice, axonal transport is demonstrably impaired several months before clinical disease onset. ${ }^{124}$ The kinesin complex of proteins are important molecular motors for anterograde axonal transport on the microtubule system. Mutations of genes encoding several kinesin proteins have been shown to cause various types of motor neurone degeneration including hereditary spastic paraplegia (SPG10) and type 2A CharcotMarie-Tooth disease, ${ }^{125} 126$ though they have not yet been associated with ALS/MND. The dynein-dynactin complex is the important motor for retrograde transport on the microtubule system, returning components (for example, multivesicular bodies and neurotrophic factors) back to the cell body. Mutations in dynein and the dynactin complex, which is an activator of cytoplasmic dynein, cause progressive motor neurone disease in mice. ${ }^{44}{ }^{127}$ As discussed in the genetics section, a dominant point mutation is the P150 subunit of dynactin, which causes a lower motor neurone disorder with vocal cord paresis in human subjects. ${ }^{43}$

\section{PROTEIN AGGREGATION}

A recurring theme highlighted in research into neurodegenerative diseases has been the misfolding of mutant proteins with the formation of intracellular aggregates. There is continuing debate as to whether such aggregated proteins play a key role in disease pathogenesis, whether they represent harmless bystanders, or whether they could be beneficial to the cell by sequestering potentially toxic abnormal proteins. In the SODl transgenic mouse model of familial ALS, the mutant SODl protein forms conspicuous cytoplasmic inclusions in motor neurones and sometimes in astrocytes, which develop before the onset of motor dysfunction. Several hypotheses have been put forward to explain how mutant SODl aggregates could produce cellular toxicity. First, there might be sequestration of other proteins required for normal motor neurone function. Several additional proteins have been found present in SODl aggregates including CCS (copper chaperone for SOD1), ubiquitin neurofilaments, glial fibrillary acidic protein, two neuronal glutamate transporters, $\mathrm{BCl} 2$, and proteins involved in chaperone and proteosome functions. ${ }^{113} 128$ Second, by repeatedly misfolding, the SODl aggregates may reduce the availability of chaperone proteins required for the folding and function of other essential intracellular proteins. ${ }^{129}$ Third, the SODl mutant protein aggregates may reduce proteasome activity needed for normal protein turnover. ${ }^{130}{ }^{131}$ Fourth, 
there could be inhibition of the function of specific organelles (for example, mitochondria) by aggregation on or within these organelles. Overexpression of chaperone proteins can reduce mutant SODl aggregation and enhances the survival and function of motor neurones in culture. ${ }^{132}$ In addition, arimoclamol-a drug which enhances the expression of heat shock proteins-increases the life span of G93A SODl mice by $22 \% .{ }^{133}$ Clearly protein aggregates, which can be identified by ubiquitin immunostaining, are a feature of sporadic as well as familial SODl related ALS. SODl containing aggregates are not a characteristic feature of sporadic ALS, and determining the nature of the protein inclusions in sporadic ALS is a key research goal.

\section{INFLAMMATORY CASCADES AND THE ROLE OF NON-NEURONAL CELLS}

Recently there has been increasing interest in the possibility that non-neuronal cells, including activated microglia and astrocytes, may contribute to the pathogenesis or propagation of the disease process in ALS/MND. Several studies in genetically engineered mouse models have indicated that expression of mutant SODl in neurones alone is insufficient to cause motor neurone degeneration and that participation of non-neuronal cells may be required. ${ }^{134}{ }^{135}$ More recently Clement and colleagues produced several sets of chimeric mice which have both normal and mutant SODl expressing cells. ${ }^{136}$ Motor neurones expressing mutant SODl could escape disease if surrounded by a sufficient number of normal non-neuronal cells. Conversely normal motor neurones surrounded by mutant SODI containing non-neuronal cells developed signs of abnormality, with the development of ubiquitinated intraneuronal deposits. Thus mutant SODl may cause neurotoxicity indirectly by disturbing the function of non-neuronal cells, for example microglia. Microglia play a critical role as resident immunocompetent and phagocytic cells within the CNS. Activation is associated with transformation to phagocytic cells capable of releasing potentially cytotoxic molecules including reactive oxygen species, nitric oxide, proteases, and proinflammatory cytokines such as interleukin-1B, tumour necrosis factor $\alpha(\mathrm{TNF} \alpha)$, and interleukin 6 (IL-6). ${ }^{137}$ Given this, there is little doubt that activated microglia can inflict significant damage on neurones, but their role is complex and they are capable of stimulating neuroprotective as well as neurotoxic effects.

Proliferation of activated microglia is a prominent histological feature in the spinal ventral horn both in mutant SODl transgenic mice and in human ALS/MND. ${ }^{138}{ }^{139}$ In the mice, microglial activation is present before the onset of significant motor neurone loss or motor weakness. Various inflammatory cytokines or enzymes are upregulated in the spinal cord or CSF of ALS/MND patients (IL-6, IL-1 $\beta$, cyclo-oxygenase 2 (COX2), and prostaglandin E2 (PGE2)) or, in the spinal cord of mutant SOD1 mice (IL-1 $\beta$, TNF $\alpha$, COX2, PGE2). ${ }^{140-143}$ Microglia appear to mediate the toxicity to neurones in culture of CSF from patients with ALS/MND by releasing factors that enhance glutamate toxicity. ${ }^{144}$ Minocycline, which inhibits microglial activation, ameliorates disease progression in mutant SODI mice. ${ }^{110}{ }^{145}$

There is a tendency in ALS/MND for the disease to start focally and to spread "like a bush fire" to contiguous groups of motor neurones. ${ }^{146}$ It would be very relevant to identify molecules that contribute to this propagation and those released from activated microglia would clearly be plausible candidates.

\section{APOPTOSIS}

Apoptosis describes the controlled removal of cells by an energy dependent cell death programme. Key molecular players contributing to the control of apoptosis include: the caspase family of proteolytic enzymes which orchestrate cell destruction by destroying several intracellular targets including structural and regulatory proteins; the $\mathrm{Bcl} 2$ family of oncoproteins, where the balance and subcellular distribution between pro- and anti-apoptotic members is important in regulating cell survival or destruction; and the apoptosis inhibitor family of proteins which suppress apoptosis by preventing proteolytic activation of specific caspases. Three main pathways triggering caspase activation have been identified including: release of proapoptotic factors (for example cytochrome c) from mitochondria; activation of cell surface ligand receptor systems of the tumour necrosis factor family including Fas-Fas ligand, with subsequent recruitment of cytosolic adaptor proteins; and stress to the endoplasmic reticulum with activation of caspase 12 .

The evidence that motor neurones may die in ALS/MND by a programmed cell death pathway has been reviewed. ${ }^{147} 148$ Key evidence from investigation of human necropsy material includes the following:

- evidence of structural morphology of degenerating motor neurones compatible with the apoptosis as well as internucleosomal DNA fragmentation detected by TUNEL staining ${ }^{149}$;

- increased expression of specific apoptosis related molecules, for example $\mathrm{Le}^{\mathrm{y}}$ antigen and prostate apoptosis response-4 protein in spinal cord;

- alteration in the balance of expression and subcellular compartmental localisation of pro- and anti-apoptotic members of the $\mathrm{Bcl} 2$ family in a direction favouring apoptosis $^{149} 150$;

- significant increases in the activities of caspases 1 and 3 in the spinal cord. ${ }^{149}$

Study of cellular models of SODl related ALS/MND has indicated that motor neuronal cells expressing mutant SODI are more likely to die by apoptosis when oxidatively stressed. ${ }^{25}$ In addition, under unstressed basal culture conditions, these mutant SODl containing cells appear to be "primed" for apoptosis by expressing increased amounts compared with control cells of phosphatidyl serine on the cell surface and increased cleavage/activation of the initiator caspase 9. ${ }^{151}$ In the mutant SODl mouse model, there is evidence of DNA laddering, increased expression and activation of caspase 1 and caspase 3 in the spinal cord of symptomatic mice, and alterations in the balance of key members of the $\mathrm{Bcl} 2$ protein family in a direction favouring apoptosis. ${ }^{152}{ }^{153}$ Cross breeding experiments between G93A SODl transgenic mice and mice genetically engineered to overexpress antiapopototic molecules results in amelioration of the murine disease. The administration of caspase inhibitors has a partial neuroprotective effect in cellular models, ${ }^{151}$ and intraventricular administration of a broad spectrum caspase inhibitor to mutant SODl mice prolongs life span by approximately $20 \%{ }^{152}$

\section{CELL SPECIFIC FEATURES OF MOTOR NEURONES WHICH MAY PREDISPOSE TO NEURODEGENERATION}

One of the unsolved enigmas in neurodegenerative diseases in general, and in motor neurone degeneration in particular, is the selective vulnerability of certain neuronal groups to the neurodegenerative process. This vulnerability is relative rather than absolute. SODl is a ubiquitously distributed antioxidant defence protein, yet when the protein is mutated, it is motor neurones that are most susceptible to injury. The cell specific features of motor neurones that may predispose to age related degeneration have been reviewed ${ }^{154155}$ and are outlined in table 4 . Key features are likely to include the cell 
Table 4 Cell specific features of motor neurones predisposing to neurodegeneration

- Cell size and axonal length

- High metabolic rate

- ? Specific features of motor neurone mitochondria

- Cytoskeleton, neurofilament content and reliance on efficient intracellular transport system

- Characteristic profile of cell surface glutamate receptors, with high relative expression of calcium permeable AMPA receptors, lacking the GluR2 subunit

- High expression of glutamate transporters in the vicinity of vulnerable motor neurone groups

- Low expression of specific calcium binding proteins

- High expression of SOD1 protein

- High threshold for mounting a heat shock response/upregulation of chaperone proteins

size of motor neurones, which has consequences for intracellular transport, energy metabolism, and neurofilament content. The neurones vulnerable to degeneration in ALS have a particular sensitivity to glutamatergic toxicity through AMPA receptor activation and differ from most other neuronal groups in expressing a high preponderance of calcium permeable AMPA receptors, which lack the GluR2 subunit. ${ }^{156}$ Motor neurones also have a relative lack of expression of calcium buffering proteins ${ }^{157}$ and appear to have a high threshold for mounting a protective heat shock response. ${ }^{158}$ Recent studies suggest that the properties of mitochondria from the spinal cord may differ from those of mitochondria from other tissues. ${ }^{112} 159$

\section{CONCLUSIONS}

The process of motor neurone degeneration in ALS/MND is complex and mutifactorial. Several genetic alterations can set the scene for motor neurone injury in familial ALS, but much remains to be learned about the genetic and environmental factors predisposing to the commoner sporadic form of the disease. Most has been learned about the mechanisms of motor neurone degeneration in the subtype of disease caused by SODl mutations, but even here there appears to be a complex interplay between multiple pathogenic processes including oxidative stress, protein aggregation, mitochondrial dysfunction excitotoxicity, and impaired axonal transport. New evidence is emerging that non-neuronal cells in the vicinity of motor neurones may contribute to neuronal injury. Evidence has accumulated that the final demise of motor neurones is likely to occur by a programmed cell death pathway resembling apoptosis.

To date only the antiglutamate agent riluzole has been shown reproducibly to prolong the survival of patients with ALS/MND, and this is a modest effect. In the recent past, robust cellular and animal models of motor neurone degeneration have emerged which are being used to evaluate new potential therapeutic strategies. New technologies including gene expression profiling using microarray platforms, ${ }^{160161}$ analysis of the repertoire of cellular proteins using proteomic approaches, ${ }^{103}{ }^{130}$ and the ability to subdissect motor neurones from complex tissues using laser capture microdissection ${ }^{162}$ are likely to lead to clarification of our knowledge of the cellular mechanisms of disease in ALS/ MND over the next few years. Important priorities for future research include the search for other genes associated with familial MND and for genetic and environmental factors predisposing to the sporadic form of the disease. In addition, further probing for insights into the cell specific biochemistry and physiology of motor neurones and the cellular pathways deranged during motor neurone degeneration are likely to lead to the development of more effective neuroprotective treatments for patients. The space constraints of this article have not permitted a detailed discussion of potential therapies targeted to the outlined molecular mechanisms of motor neurone injury. This topic has recently been reviewed in relation both to experimental models and to human MND. ${ }^{16}{ }^{163}$ Future treatment of ALS/MND is likely to involve a cocktail of neuroprotective compounds akin to chemotherapeutic combinations for malignant disease, which interfere with several molecular pathways that lead to neuronal injury.

\section{ACKNOWLEDGEMENTS}

PJS is supported by the Wellcome Trust, the Motor Neurone Disease Association, and the Medical Research Council.

Competing interests: none declared

\section{REFERENCES}

1 Maasilta $\mathbf{P}$, Jokelainen $M$, Loytonen $M$, et al. Mortality from amyotrophic lateral sclerosis in Finland, 1986-1995. Acta Neurol Scand $2001 ; 104: 232-5$.

2 Rowland LP. Clinical aspects of sporadic ALS/MND. In: Shaw PJ, Strong MJ, eds. Blue book of practical neurology: motor neuron disorders. Philadelphia: Heinemann, 2003:111-44.

3 Charcot JM, Joffroy A. Deux cas d'atrophie musculaire progressive avec lesions de la substance grise et des faisceaux antero-lateraux de la moelle epiniere. Arch Physiol Neurol Pathol 1869;2:744.

4 Ince PG, Tomkins J, Slade JY, et al. Amyotrophic lateral sclerosis associated with genetic abnormalities in the gene encoding $\mathrm{Cu} / \mathrm{Zn}$ superoxide dismutase: molecular pathology of five new cases, and comparison with previous reports and 73 sporadic cases of ALS. J Neuropathol Exp Neurol 1998;57:895-904

5 Mannen T, Iwata M, Toyokura Y, et al. Preservation of a certain motoneurone group of the sacral cord in amyotrophic lateral sclerosis: its clinical significance. J Neurol Neurosurg Psychiatry 1977:40:464-9.

6 del Aguila MA, Longstreth WT, McGuire V, et al. Prognosis in amyotrophic lateral sclerosis: a population-based study. Neurology 2003;60:813-19.

7 Turner MR, Parton MJ, Shaw CE, et al. Prolonged survival in motor neuron disease: a descriptive study of the King's database 1990-2002. J Neurol Neurosurg Psychiatry 2003;74:995-7.

8 Brooks BR, Miller RG, Swash M, et al. El Escorial revisited: revised criteria for the diagnosis of amyotrophic lateral sclerosis. Amyotroph Lateral Scler Other Motor Neuron Disord 2000; 1:293-9.

9 Wharton SP. Pathology of motor neuron disorders. In: Shaw PJ Strong MJ, eds. Blue books of practical neurology: motor neuron disorders. Philadelphia: Butterworth-Heinemann, 2003:17-50.

10 Hudson AJ. Amyotrophic lateral sclerosis and its association with dementia, parkinsonism and other neurological disorders: a review. Brain $1981 ; 104: 217-47$

11 Massman PJ, Sims J, Cooke N, et al. Prevalence and correlates of neuropsychological deficits in amyotrophic lateral sclerosis. J Neurol Neurosurg Psychiatry 1996:61:450-5.

12 Rosen DR, Siddique T, Patterson D et al. Mutations in Cu/Zn superoxide dismutase gene are associated with familial amyotrophic lateral sclerosis. Nature 1993;364:362.

13 Andersen PM, Sims KB, Xin WW, et al. Sixteen novel mutations in the Cu/Zn superoxide dismutase gene in amyotrophic lateral sclerosis: a decade of discoveries, defects and disputes. Amyotroph Lateral Scler Other Motor Neuron Disord 2003;4:62-73.

$14 \mathrm{http}: / /$ www.alsod.org.

15 Okado-Matsumoto A, Fridovich I. Subcellular distribution of superoxide dismutases (SOD) in rat liver: $\mathrm{Cu}, \mathrm{Zn}-\mathrm{SOD}$ in mitochondria. J Biol Chem 2001;276:38388-93.

16 Bruijn LI, Miller TM, Cleveland DW. Unraveling the mechanisms involved in motor neuron degeneration in ALS. Annu Rev Neurosci 2004;27:723-49.

17 Andersen PM, Forsgren L, Binzer M, et al. Autosomal recessive adult-onset amyotrophic lateral sclerosis associated with homozygosity for Asp90Ala CuZn-superoxide dismutase mutation. A clinical and genealogical study of 36 patients. Brain 1996;119:1153-72.

18 Cudkowicz ME, McKenna-Yasek D, Sapp PE, et al. Epidemiology of mutations in superoxide dismutase in amyotrophic lateral sclerosis. Ann Neurol 1997;41:210-21.

19 Kunst CB, Messer L, Gordon J, et al. Genetic mapping of a mouse modifier gene that can prevent ALS onset. Genomics 2000;70:181-9. 
20 Wong PC, Pardo CA, Borchelt DR, et al. An adverse property of a familial ALS-linked SODI mutation causes motor neuron disease characterized by vacuolar degeneration of mitochondria. Neuron 1995;14:1105-16.

21 Gurney ME, Pu H, Chiu AY, et al. Motor neuron degeneration in mice that express a human $\mathrm{Cu} / \mathrm{Zn}$ superoxide dismutase mutation. Science 1994;264:1772-5.

22 Bruijn LI, Cleveland DW. Mechanisms of selective motor neuron death in ALS: insights from transgenic mouse models of motor neuron disease. Neuropathol Appl Neurobiol 1996;22:373-87.

23 Nagai M, Aoki M, Miyoshi I, et al. Rats expressing human cytosolic copperzinc superoxide dismutase transgenes with amyotrophic lateral sclerosis: associated mutations develop motor neuron disease. J Neurosci 2001;21:9246-54

24 Howland DS, Liu J, She $Y$, et al. Focal loss of the glutamate transporter EAAT2 in a transgenic rat model of SOD1 mutant-mediated amyotrophic lateral sclerosis (ALS). Proc Natl Acad Sci USA 2002;99:1604-9.

25 Cookson MR, Menzies FM, Manning P, et al. Cu/Zn superoxide dismutase (SOD1) mutations associated with familial amyotrophic lateral sclerosis (ALS) affect cellular free radical release in the presence of oxidative stress. Amyotroph Lateral Scler Other Motor Neuron Disord 2002;3:75-85.

26 Pasinelli P, Borchelt DR, Houseweart MK, et al. Caspase-1 is activated in neural cells and tissue with amyotrophic lateral sclerosis-associated mutations in copper-zinc superoxide dismutase. Proc Natl Acad Sci USA 1998:95:15763-8.

27 Roy J, Minotti S, Dong L, et al. Glutamate potentiates the toxicity of mutant $\mathrm{Cu} / \mathrm{Zn}$-superoxide dismutase in motor neurons by postsynaptic calciumdependent mechanisms. J Neurosci 1998;18:9673-84.

28 Hadano S, Hand CK, Osuga $\mathrm{H}$, et al. A gene encoding a putative GTPase regulator is mutated in familial amyotrophic lateral sclerosis 2. Nat Genet 2001;29:166-73.

29 Yang $Y$, Hentati A, Deng HX, et al. The gene encoding alsin, a protein with three guanine-nucleotide exchange factor domains, is mutated in a form of recessive amyotrophic lateral sclerosis. Nat Genet 2001;29:160-5.

30 Eymard-Pierre E, Lesca G, Dollet S, et al. Infantile-onset ascending hereditary spastic paralysis is associated with mutations in the alsin gene. Am J Hum Genet 2002;71:518-27.

31 Devon RS, Helm JR, Rouleau GA, et al. The first nonsense mutation in alsin results in a homogeneous phenotype of infantile-onset ascending spastic paralysis with bulbar involvement in two siblings. Clin Genet 2003;64:210-15.

32 Gros-Louis F, Meijer IA, Hand CK, et al. An ALS2 gene mutation causes hereditary spastic paraplegia in a Pakistani kindred. Ann Neurol 2003;53:144-5.

33 Vetter IR, Wittinghofer A. The guanine nucleotide-binding switch in three dimensions. Science 2001;294:1299-304.

34 Yamanaka K, Vande Velde C, Eymard-Pierre E, et al. Unstable mutants in the peripheral endosomal membrane component ALS2 cause early-onset motor neuron disease. Proc Natl Acad Sci USA 2003;100:16041-6.

35 Otomo A, Hadano S, Okada T, et al. ALS2, a novel guanine nucleotide exchange factor for the small GTPase Rab5, is implicated in endosomal dynamics. Hum Mol Genet 2003;12:1671-87.

36 Kunita R, Otomo A, Mizumura H, et al. Homo-oligomerization of ALS2 through its unique carboxyl-terminal regions is essential for the ALS2associated Rab5 guanine nucleotide exchange activity and its regulatory function on endosome trafficking. J Biol Chem 2004;279:38626-35.

37 Kris J, Millecamps S, Zhu Q, et al. Creation of a mouse model for juvenile amyotrophic lateral sclerosis. Amyotroph Lateral Scler Other Motor Neuron Disord 2003;4(suppl 1):11

38 Cai H, Wen H, Chaing HC, et al. Physiological role of ALS2: selective vulnerability and generation of ALS2 knockout mice. Amyotroph Lateral Scler Other Motor Neuron Disord 2003;4(suppl 1):11-12.

39 Kanekura K, Hashimoto Y, Niikura T, et al. Alsin, the product of ALS2 gene, suppresses SOD1 mutant neurotoxicity through RhoGEF domain by interacting with SODI mutants. J Biol Chem 2004:279:19247-56.

40 Chen YZ, Bennett $\mathrm{CL}$, Huynh HM, et al. DNA/RNA helicase gene mutations in a form of juvenile amyotrophic lateral sclerosis (ALS4). Am J Hum Genet 2004;74:1128-35

41 Moreira MC, Klur S, Watanabe M, et al. Senataxin, the ortholog of a yeast RNA helicase, is mutant in ataxia-ocular apraxia 2. Nat Genet 2004:36:225-7.

42 Nishimura AL, Mitne-Neto M, Silva HC, et al. A mutation in the vesicletrafficking protein VAPB causes late-onset spinal muscular atrophy and amyotrophic lateral sclerosis. Am J Hum Genet 2004;75:822-31.

43 Puls I, Jonnakuty C, LaMonte BH, et al. Mutant dynactin in motor neuron disease. Nat Genet 2003;33:455-6.

44 LaMonte BH, Wallace KE, Holloway BA, et al. Disruption of dynein/dynactin inhibits axonal transport in motor neurons causing late-onset progressive degeneration. Neuron 2002;34:715-27.

45 Hosler BA, Siddique T, Sapp PC, et al. Linkage of familial amyotrophic lateral sclerosis with frontotemporal dementia to chromosome 9q21-q22. JAMA 2000;284:1664-9

46 Ostojic J, Axelman K, Lannfelt L, et al. No evidence of linkage to chromosome 9q21-22 in a Swedish family with frontotemporal dementia and amyotrophic lateral sclerosis. Neurosci Lett 2003;340:245-7.

47 Clark LN, Poorkaj P, Wszolek Z, et al. Pathogenic implications of mutations in the tau gene in pallido-ponto-nigral degeneration and related neurodegenerative disorders linked to chromosome 17. Proc Natl Acad Sci USA 1998:95:13103-7.

48 Hutton M, Lendon CL, Rizzu P, et al. Association of missense and 5'-splicesite mutations in tau with the inherited dementia FTDP-17. Nature 1998;393:702-5.
49 Kowalska A, Konagaya M, Sakai M, et al. Familial amyotrophic lateral sclerosis and parkinsonism-dementia complex--tauopathy without mutations in the tau gene? Folia Neuropathol 2003;41:59-64

50 Wilhelmsen KC, Forman MS, Rosen $\mathrm{HJ}$, et al. 17q-linked frontotemporal dementia-amyotrophic lateral sclerosis without tau mutations with tau and alpha-synuclein inclusions. Arch Neurol 2004;61:398-406

51 Figlewicz DA, Krizus A, Martinoli MG, et al. Variants of the heavy neurofilament subunit are associated with the development of amyotrophic lateral sclerosis. Hum Mol Genet 1994;3:1757-61.

52 Tomkins J, Usher P, Slade JY, et al. Novel insertion in the KSP region of the neurofilament heavy gene in amyotrophic lateral sclerosis (ALS). Neuroreport 1998;9:3967-70.

53 Al-Chalabi A, Enayat ZE, Bakker MC, et al. Association of apolipoprotein E epsilon 4 allele with bulbar-onset motor neuron disease. Lancet 1996;347:159-60.

54 Drory VE, Birnbaum M, Korczyn AD, et al. Association of APOE epsilon4 allele with survival in amyotrophic lateral sclerosis. J Neurol Sci 2001;190:17-20.

55 Comi GP, Bordoni A, Salani S, et al. Cyłochrome c oxidase subunit I microdeletion in a patient with motor neuron disease. Ann Neurol 1998;43:110-16.

56 Rothstein JD, Van Kammen M, Levey Al, et al. Selective loss of glial glutamate transporter GLT-1 in amyotrophic lateral sclerosis. Ann Neurol 1995; 38:73-84

57 Rao SD, Yin HZ, Weiss JH. Disruption of glial glutamate transport by reactive oxygen species produced in motor neurons. J Neurosci 2003;23:2627-33.

58 Fray AE, Ince PG, Banner SJ, et al. The expression of the glial glutamate transporter protein EAAT2 in motor neuron disease: an immunohistochemical study. Eur J Neurosci 1998;10:2481-9.

59 Lin CL, Bristol LA, Jin L, et al. Aberrant RNA processing in a neurodegenerative disease: the cause for absent EAAT2, a glutamate transporter, in amyotrophic lateral sclerosis. Neuron 1998;20:589-602.

60 Meyer T, Fromm A, Munch C, et al. The RNA of the glutamate transporter EAAT2 is variably spliced in amyotrophic lateral sclerosis and normal individuals. J Neurol Sci 1999;170:45-50.

61 Flowers JM, Powell JF, Leigh PN, et al. Intron 7 retention and exon 9 skipping EAAT2 mRNA variants are not associated with amyotrophic lateral sclerosis. Ann Neurol 2001;49:643-9.

62 Trotti D, Aoki M, Pasinelli P, et al. Amyotrophic lateral sclerosis-linked glutamate transporter mutant has impaired glutamate clearance capacity. J Biol Chem $2001 ; 276: 576-82$.

63 Kawahara Y, Ito K, Sun H, et al. Glutamate receptors: RNA editing and death of motor neurons. Nature 2004:427:801.

64 Jackson M, Morrison KE, Al-Chalabi A, et al. Analysis of chromosome 5 q13 genes in ALS: homozygous NAIP deletion in a sporadic case. Ann Neurol 1996;39:796-800

65 Orrell RW, Habgood JJ, de Belleroche JS, et al. The relationship of spinal muscular atrophy to motor neuron disease: investigation of SMN and NAIP gene deletions in sporadic and familial amyotrophic lateral sclerosis. J Neurol Sci 1997; 145:55-61.

66 Veldink JH, van den Berg LH, Cobben JM, et al. Homozygous deletion of the survival motor neuron 2 gene is a prognostic factor in sporadic ALS. Neurology 2001;56:749-52.

67 Corcia P, Mayeux-Portas V, Khoris J, et al. Abnormal SMN1 gene copy number is a susceptibility factor for amyotrophic lateral sclerosis. Ann Neurol 2002;51:243-6.

68 Giess R, Holtmann B, Braga $M$, et al. Early onset of severe familial amyotrophic lateral sclerosis with a SOD-1 mutation: potential impact of CNTF as a candidate modifier gene. Am J Hum Genet 2002;70:1277-86.

69 Brockington A, Lewis C, Wharton S, et al. Vascular endothelial growth factor and the nervous system. Neuropathol Appl Neurobiol 2004;30:427-46.

70 Lambrechts D, Storkebaum E, Morimoto M, et al. VEGF is a modifier of amyotrophic lateral sclerosis in mice and humans and protects motoneurons against ischemic death. Nat Genet 2003;34:383-94.

71 Oosthuyse B, Moons L, Storkebaum E, et al. Deletion of the hypoxiaresponse element in the vascular endothelial growth factor promoter causes motor neuron degeneration. Nat Genet 2001;28:131-8.

72 Brockington A, Kirby J, Eggitt D, et al. Screening of the regulatory and coding regions of vascular endothelial growth factor in amyotrophic lateral sclerosis. Neurogenetics, 2005, March 18 [Epub ahead of print].

73 Gros-Louis F, Laurent S, Lopes AA, et al. Absence of mutations in the hypoxia response element of VEGF in ALS. Muscle Nerve 2003;28:774-5.

74 Shaw PJ, Ince PG, Falkous G, et al. Oxidative damage to protein in sporadic motor neuron disease spinal cord. Ann Neurol 1995;38:691-5.

75 Ferrante RJ, Browne SE, Shinobu LA, et al. Evidence of increased oxidative damage in both sporadic and familial amyotrophic lateral sclerosis. J Neurochem 1997:69:2064-74.

76 Smith RG, Henry YK, Mattson MP, et al. Presence of 4-hydroxynonenal in cerebrospinal fluid of patients with sporadic amyotrophic lateral sclerosis. Ann Neurol 1998;44:696-9.

77 Tohgi H, Abe T, Yamazaki K, et al. Remarkable increase in cerebrospinal fluid 3-nitrotyrosine in patients with sporadic amyotrophic lateral sclerosis. Ann Neurol 1999:46:129-31.

78 Aguirre T, Van Den Bosch L, Goetschalckx K, et al. Increased sensitivity of fibroblasts from amyotrophic lateral sclerosis patients to oxidative stress. Ann Neurol 1998;43:452-7.

79 Beckman JS, Carson M, Smith CD, et al. ALS, SOD and peroxynitrite. Nature 1993;364:584.

80 Crow JP, Sampson JB, Zhuang Y, et al. Decreased zinc affinity of amyotrophic lateral sclerosis-associated superoxide dismutase mutants leads 
to enhanced catalysis of tyrosine nitration by peroxynitrite. I Neurochem 1997;69:1936-44.

81 Estevez AG, Crow JP, Sampson JB, et al. Induction of nitric oxide-dependent apoptosis in motor neurons by zinc-deficient superoxide dismutase. Science 1999:286:2498-500.

82 Wang J, Slunt H, Gonzales V, et al. Copper-binding-site-null SOD1 causes ALS in transgenic mice: aggregates of non-native SODI delineate a common feature. Hum Mol Genet 2003;12:2753-64.

83 Subramaniam JR, Lyons WE, Liu J, et al. Mutant SOD1 causes motor neuron disease independent of copper chaperone-mediated copper loading. Nat Neurosci 2002;5:301-7.

84 Facchinetti F, Sasaki M, Cutting FB, et al. Lack of involvement of neuronal nitric oxide synthase in the pathogenesis of a transgenic mouse model of familial amyotrophic lateral sclerosis. Neuroscience 1999;90:1483-92.

85 Upton-Rice MN, Cudkowicz ME, Mathew RK, et al. Administration of nitric oxide synthase inhibitors does not alter disease course of amyotrophic lateral sclerosis SOD1 mutant transgenic mice. Ann Neurol 1999:45:413-14.

86 Son M, Fathallah-Shaykh HM, Elliott JL. Survival in a transgenic model of FALS is independent of iNOS expression. Ann Neurol 2001;50:273.

87 Carriedo SG, Yin HZ, Weiss JH. Motor neurons are selectively vulnerable to AMPA/kainate receptor-mediated injury in vitro. J Neurosci 1996;16:4069-79.

88 Heath PR, Shaw PJ. Update on the glutamatergic neurotransmitter system and the role of excitotoxicity in amyotrophic lateral sclerosis. Muscle Nerve 2002;26:438-58.

89 Shaw PJ, Forrest $\mathrm{V}$, Ince PG et al. CSF and plasma amino acid levels in motor neuron disease: elevation of CSF glutamate in a subset of patients. Neurodegeneration 1995;4:209-16

90 Spreux-Varoquaux O, Bensimon G, Lacomblez L, et al. Glutamate levels in cerebrospinal fluid in amyotrophic lateral sclerosis: a reappraisal using a new HPLC method with coulometric detection in a large cohort of patients. J Neurol Sci 2002;193:73-8.

91 Kruman II, Pedersen WA, Springer JE, et al. ALS-linked Cu/Zn-SOD mutation increases vulnerability of motor neurons to excitotoxicity by a mechanism involving increased oxidative stress and perturbed calcium homeostasis. Exp Neurol 1999; 160:28-39.

92 Spalloni A, Albo F, Ferrari F, et al. Cu/Zn-superoxide dismutase $($ GLY93 $\rightarrow$ ALA) mutation alters AMPA receptor subunit expression and function and potentiates kainate-mediated toxicity in motor neurons in culture. Neurobiol Dis 2004:15:340-50.

93 Bendotti C, Tortarolo M, Suchak SK, et al. Transgenic SODI G93A mice develop reduced GLT-1 in spinal cord without alterations in cerebrospinal fluid glutamate levels. J Neurochem 2001;79:737-46.

94 Lacomblez L, Bensimon G, Leigh PN, et al. Dose-ranging study of riluzole in amyotrophic lateral sclerosis. Amyotrophic Lateral Sclerosis/Riluzole Study Group II. Lancet 1996;347:1425-31

95 Gurney ME, Cutting FB, Zhai $P$, et al. Benefit of vitamin E, riluzole, and gabapentin in a transgenic model of familial amyotrophic lateral sclerosis. Ann Neurol 1996;39:147-57.

96 Beal MF. Mitochondria and the pathogenesis of ALS. Brain 2000;123:1291-2

97 Menzies FM, Ince PG, Shaw PJ. Mitochondrial involvement in amyotrophic lateral sclerosis. Neurochem Int 2002; $40: 543-51$.

98 Siklos L, Engelhardt J, Harati Y, et al. Ultrastructural evidence for altered calcium in motor nerve terminals in amyotropic lateral sclerosis. Ann Neurol 1996:39:203-16.

99 Borthwick GM, Johnson MA, Ince PG, et al. Mitochondrial enzyme activity in amyotrophic lateral sclerosis: implications for the role of mitochondria in neuronal cell death. Ann Neurol 1999;46:787-90.

100 Dhaliwal GK, Grewal RP. Mitochondrial DNA deletion mutation levels are elevated in ALS brains. Neuroreport 2000;11:2507-9.

101 Wiedemann FR, Manfredi G, Mawrin C, et al. Mitochondrial DNA and respiratory chain function in spinal cords of ALS patients. I Neurochem 2002;80:616-25.

102 Menzies FM, Cookson MR, Taylor RW, et al. Mitochondrial dysfunction in a cell culture model of familial amyotrophic lateral sclerosis. Brain 2002; 125:1522-33

103 Fukada K, Zhang F, Vien A, et al. Mitochondrial proteomic analysis of a cell line model of familial amyotrophic lateral sclerosis. Mol Cell Proteomics 2004:3:1211-23.

104 Takeuchi H, Kobayashi Y, Ishigaki S, et al. Mitochondrial localization of mutant superoxide dismutase 1 triggers caspase-dependent cell death in a cellular model of familial amyotrophic lateral sclerosis. J Biol Chem 2002;277:50966-72.

105 Higgins $\mathrm{CM}$, Jung $\mathrm{C}$, Ding $\mathrm{H}$, et al. Mutant $\mathrm{Cu}, \mathrm{Zn}$ superoxide dismutase that causes motoneuron degeneration is present in mitochondria in the CNS $J$ Neurosci 2002;22:RC215.

106 Jaarsma D, Rognoni F, van Duijn W, et al. CuZn superoxide dismutase (SODI) accumulates in vacuolated mitochondria in transgenic mice expressing amyotrophic lateral sclerosis-linked SOD1 mutations. Acto Neuropathol (Berl) 2001;102:293-305.

107 Jung C, Higgins CM, Xu Z. A quantitative histochemical assay for activities of mitochondrial electron transport chain complexes in mouse spinal cord sections. J Neurosci Methods 2002;114:165-72.

108 Mattiazzi M, D'Aurelio M, Gajewski CD, et al. Mutated human SOD1 causes dysfunction of oxidative phosphorylation in mitochondria of transgenic mice. J Biol Chem 2002;277:29626-33.

109 Guegan C, Vila M, Rosoklija G, et al. Recruitment of the mitochondrialdependent apoptotic pathway in amyotrophic lateral sclerosis. J Neurosci 2001;21:6569-76.
110 Zhu S, Stavrovskaya IG, Drozda M, et al. Minocycline inhibits cytochrome c release and delays progression of amyotrophic lateral sclerosis in mice. Nature 2002;417:74-8.

111 Andreassen OA, Ferrante RJ, Klivenyi P, et al. Partial deficiency of manganese superoxide dismutase exacerbates a transgenic mouse model of amyotrophic lateral sclerosis. Ann Neurol 2000;47:447-55.

112 Liv J, Lillo C, Jonsson PA, et al. Toxicity of familial ALS-linked SOD1 mutants from selective recruitment to spinal mitochondria. Neuron 2004;43:5-17.

113 Pasinelli $\mathbf{P}$, Belford ME, Lennon N, et al. Amyotrophic lateral sclerosisassociated SOD1 mutant proteins bind and aggregate with $\mathrm{Bcl}-2$ in spinal cord mitochondria. Neuron 2004;43:19-30.

114 Klivenyi P, Ferrante RJ, Matthews RT, et al. Neuroprotective effects of creatine in a transgenic animal model of amyotrophic lateral sclerosis. Nat Med 1999:5:347-50.

115 Xu Z, Cork LC, Griffin JW, et al. Increased expression of neurofilament subunit NF-L produces morphological alterations that resemble the pathology of human motor neuron disease. Cell 1993;73:23-33.

116 Cote F, Collard JF, Julien JP. Progressive neuronopathy in transgenic mice expressing the human neurofilament heary gene: a mouse model of amyotrophic lateral sclerosis. Cell 1993;73:35-46.

117 Lee MK, Marszalek JR, Cleveland DW. A mutant neurofilament subunit causes massive, selective motor neuron death: implications for the pathogenesis of human motor neuron disease. Neuron 1994;13:975-88.

118 Tu PH, Raju P, Robinson KA, et al. Transgenic mice carrying a human mutant superoxide dismutase transgene develop neuronal cytoskeletal pathology resembling human amyotrophic lateral sclerosis lesions. Proc Natl Acad Sci USA 1996;93:3155-60.

119 Zhang B, Tu P, Abtahian F, et al. Neurofilaments and orthograde transport are reduced in ventral root axons of transgenic mice that express human SOD1 with a G93A mutation. J Cell Biol 1997;139:1307-15.

120 Couillard-Despres S, Zhu Q, Wong PC, et al. Protective effect of neurofilament heavy gene overexpression in motor neuron disease induced by mutant superoxide dismutase. Proc Natl Acad Sci USA 1998:95:9626-30.

121 Beaulieu JM, Nguyen MD, Julien JP. Late onset of motor neurons in mice overexpressing wild-type peripherin. J Cell Biol 1999;147:531-44

122 Robertson J, Doroudchi MM, Nguyen MD, et al. A neurotoxic peripherin splice variant in a mouse model of ALS. J Cell Biol 2003;160:939-49.

123 Lariviere RC, Beaulieu JM, Nguyen MD, et al. Peripherin is not a contributing factor to motor neuron disease in a mouse model of amyotrophic lateral sclerosis caused by mutant superoxide dismutase. Neurobiol Dis 2003;13:158-66.

124 Williamson TL, Cleveland DW. Slowing of axonal transport is a very early event in the toxicity of ALS-linked SOD1 mutants to motor neurons. Nat Neurosci 1999;2:50-6.

125 Reid E, Kloos M, Ashley-Koch A, et al. A kinesin heavy chain (KIF5A) mutation in hereditary spastic paraplegia (SPG10). Am J Hum Genet 2002;71:1189-94

126 Zhao C, Takita J, Tanaka Y, et al. Charcot-Marie-Tooth disease type 2A caused by mutation in a microtubule motor KIF1Bbeta. Cell $2001 ; 105: 587-97$

127 Hafezparast $M$, Klocke R, Ruhrberg $C$, et al. Mutations in dynein link motor neuron degeneration to defects in retrograde transport. Science 2003;300:808-12.

128 Watanabe M, Dykes-Hoberg M, Culotta VC, et al. Histological evidence of protein aggregation in mutant SOD1 transgenic mice and in amyotrophic ateral sclerosis neural tissues. Neurobiol Dis 2001:8:933-41.

129 Bruening W, Roy J, Giasson B, et al. Up-regulation of protein chaperones preserves viability of cells expressing toxic $\mathrm{Cu} / \mathrm{Zn}$-superoxide dismutase mutants associated with amyotrophic lateral sclerosis. J Neurochem 1999;72:693-9.

130 Allen S, Heath PR, Kirby J, et al. Analysis of the cytosolic proteome in a cell culture model of familial amyotrophic lateral sclerosis reveals alterations to the proteasome, antioxidant defenses, and nitric oxide synthetic pathways. $J$ Biol Chem 2003;278:6371-83.

131 Johnston JA, Dalton MJ, Gurney ME, et al. Formation of high molecular weight complexes of mutant $\mathrm{Cu}, \mathrm{Zn}$-superoxide dismutase in a mouse model for familial amyotrophic lateral sclerosis. Proc Natl Acad Sci USA 2000;97:12571-6.

132 Takeuchi H, Kobayashi Y, Yoshihara T, et al. Hsp70 and Hsp40 improve neurite outgrowth and suppress intracytoplasmic aggregate formation in cultured neuronal cells expressing mutant SOD1. Brain Res 2002;949:1 1-22.

133 Kieran D, Kalmar B, Dick JR, et al. Treatment with arimoclomol, a coinducer of heat shock proteins, delays disease progression in ALS mice. Nat Med 2004; 10:402-5

134 Pramatarova A, Laganiere J, Roussel J, et al. Neuron-specific expression of mutant superoxide dismutase 1 in transgenic mice does not lead to motor impairment. J Neurosci 2001:21:3369-74.

135 Lino MM, Schneider C, Caroni P. Accumulation of SOD1 mutants in postnatal motoneurons does not cause motoneuron pathology or motoneuron disease. J Neurosci 2002;22:4825-32.

136 Clement AM, Nguyen MD, Roberts EA, et al. Wild-type nonneuronal cells extend survival of SOD1 mutant motor neurons in ALS mice. Science 2003;302:113-17

137 Gonzalez-Scarano F, Baltuch G. Microglia as mediators of inflammatory and degenerative diseases. Annu Rev Neurosci 1999;22:219-40.

138 Alexianu ME, Kozovska M, Appel SH. Immune reactivity in a mouse model of familial ALS correlates with disease progression. Neurology 2001;57:1282-9. 
139 Kawamata T, Akiyama H, Yamada T, et al. Immunologic reactions in amyotrophic lateral sclerosis brain and spinal cord tissue. Am J Pathol 1992;140:691-707.

140 Sekizawa T, Openshaw H, Ohbo K, et al. Cerebrospinal fluid interleukin 6 in amyotrophic lateral sclerosis: immunological parameter and comparison with inflammatory and non-inflammatory central nervous system diseases. J Neurol Sci 1998;154:194-9.

141 Hensley K, Floyd RA, Gordon B, et al. Temporal patterns of cytokine and apoptosis-related gene expression in spinal cords of the G93A-SOD1 mouse model of amyotrophic lateral sclerosis. J Neurochem 2002;82:365-74.

142 Almer G, Teismann P, Stevic Z, et al. Increased levels of the proinflammatory prostaglandin PGE2 in CSF from ALS patients. Neurology 2002;58:1277-9.

143 Elliott JL. Cytokine upregulation in a murine model of familial amyotrophic lateral sclerosis. Brain Res Mol Brain Res 2001 ;95:172-8.

144 Tikka TM, Vartiainen NE, Goldsteins G, et al. Minocycline prevents neurotoxicity induced by cerebrospinal fluid from patients with motor neurone disease. Brain 2002;125:722-31.

145 Zhang W, Narayanan M, Friedlander RM. Additive neuroprotective effects of minocycline with creatine in a mouse model of ALS. Ann Neurol 2003;53:267-70.

146 Brooks BR, Shodis KA, Lewis DH, et al. Natural history of amyotrophic lateral sclerosis. Quantification of symptoms, signs, strength, and function. Adv Neurol 1995;68:163-84.

147 Sathasivam S, Ince PG, Shaw PJ. Apoptosis in amyotrophic lateral sclerosis: a review of the evidence. Neuropathol Appl Neurobiol 2001;27:257-74.

148 Guegan C, Przedborski S. Programmed cell death in amyotrophic lateral sclerosis. J Clin Invest 2003;111:153-61.

149 Martin LJ. Neuronal death in amyotrophic lateral sclerosis is apoptosis: possible contribution of a programmed cell death mechanism. J Neuropathol Exp Neurol 1999;58:459-71.

$150 \mathrm{Mu} \mathrm{X}, \mathrm{He} \mathrm{J}$, Anderson DW, et al. Altered expression of bcl-2 and bax mRNA in amyotrophic lateral sclerosis spinal cord motor neurons. Ann Neurol 1996:40:379-86.

151 Sathasivam S, Grierson AJ, Shaw PJ. Characterisation of the caspase cascade in a cell culture model of SOD1-related FALS: expression, activation and therapeutic effects of inhibition. Neuropath Appl Neurobiol (in press).
152 Li M, Ona VO, Guegan C, et al. Functional role of caspase- 1 and caspase-3 in an ALS transgenic mouse model. Science 2000;288:335-9.

153 Vukosavic S, Dubois-Dauphin M, Romero N, et al. Bax and Bcl-2 interaction in a transgenic mouse model of familial amyotrophic lateral sclerosis. J Neurochem 1999;73:2460-8.

154 Shaw PJ, Eggett CJ. Molecular factors underlying selective vulnerability of motor neurons to neurodegeneration in amyotrophic lateral sclerosis. J Neurol 2000;247(suppl 1):117-27.

155 Durham HD. Factors underlying the selective vulnerability of motor neurons to neurodegeneration. In: Shaw PJ, Strong MJ, eds. Blue books of practical neurology: motor neuron disorders. Philadelphia: Butterworth Heinemann, 2003:379-400.

156 Williams TL, Day NC, Ince PG, et al. Calcium-permeable alpha-amino-3hydroxy-5-methyl-4-isoxazole propionic acid receptors: a molecular determinant of selective vulnerability in amyotrophic lateral sclerosis. Ann Neurol 1997;42:200-7.

157 Ince P, Stout N, Shaw P, et al. Parvalbumin and calbindin D-28k in the human motor system and in motor neuron disease. Neuropathol Appl Neurobiol 1993;19:291-9.

158 Batulan ZB, Minotti S, Figlewicz DA, et al. High threshold for activation of the stress response in motor neurons: a source of vulnerability in ALS? Society of Neuroscience Abstracts 2000;26:85.15.

159 Sullivan PG, Rabchevsky AG, Keller JN, et al. Intrinsic differences in brain and spinal cord mitochondria: Implication for therapeutic interventions. J Comp Neurol 2004;474:524-34.

160 Kirby J, Halligan E, Baptista MJ, et al. Mutant SOD1 alters the motor neuronal transcriptome: implications for familial ALS. Brain (in press).

161 Olsen MK, Roberds SL, Ellerbrock BR, et al. Disease mechanisms revealed by transcription profiling in SOD1-G93A transgenic mouse spinal cord. Ann Neurol 2001;50:730-40.

162 Heath PR, Tomkins J, Ince PG, et al. Quantitative assessment of AMPA receptor mRNA in human spinal motor neurons isolated by laser capture microdissection. Neuroreport 2002;13:1753-7.

163 Turner MR, Leigh PN. Disease-modifying therapies in motor neuron disorders: the present position and potential future developments. In: Shaw PJ, Strong MJ, eds. Blue books of practical neurology: motor neuron disorders. Philadelphia: Butterworth-Heinemann, 2003:497-544. 